\title{
1. Introduction: the dynamics of regional migration governance
}

\author{
Andrew Geddes, Marcia Vera Espinoza, Leila \\ Hadj Abdou and Leiza Brumat
}

\section{INTRODUCTION}

It is a truism to observe that international migration is and will continue to be one of the most pressing concerns in global politics. The motives for migration as well as the direction, distance and duration of that movement have and will continue to have important social, economic and political effects that play out across various governance 'levels' ranging from cities, neighbourhoods and communities to the global. This book focuses on the dynamics of regional migration governance, by which is meant cooperation between states usually defined by their geographical proximity on aspects of migration and mobility. A fixation with levels should not disguise the deeper significance of regional migration governance. 'Going regional' can imply new rules that can bind state behaviour, or it can involve the development of new ideas and practices that can change the behaviour of states. Regions sit between the national and the international. Much international migration occurs within regions between neighbouring or nearby states and is thus regionalised. There is also actually existing regional migration governance of various types across the world. The chapters in this book cast new light on why, how and with what effects states cooperate with each other in such regional groupings of various types on aspects of international migration and mobility while also showing how and why international migration can also lead to tensions between states that can prevent or hinder cooperation.

The book's scope is wide, covering forms and patterns of regional cooperation on migration and mobility in Africa, Southeast Asia, Central Asia, Eurasia, Europe, the Middle East, North America and South America. The analyses in the chapters that follow seek to account for the many and varying forms that such regional organisations can take. These variations include both the organisational and institutional form, as well as the types of interna- 
tional migration and mobility that are included within regional cooperation frameworks. We distinguish between 'mobility' and 'international migration' because there are important instances of regional cooperation to promote mobility or free movement between participating states, which introduces a legal and political distinction between those who move between states within the regional grouping (labelled mobility) and those who move from outside this regional setting (labelled international migration). We also conceptualise states as non-monolithic entities, formed by different components, which have a variety of ideas, identities and interests, which could sometimes lead to apparently contradictory positions on openness and closure to migration and mobility.

The focus for the analyses contained within this book can be quite simply stated - the dynamics of regional migration governance - but this point of reference actually requires much closer examination. Analyses of regional cooperation and integration have more commonly focused on economic- and trade-related aspects of regional integration (for an overview see Börzel and Risse 2016). This is not surprising, as these aspects have typically been to the fore as key driving forces in regional cooperation and integration. Scholars of international migration have tended to devote less attention to regional integration, although this is beginning to change (e.g. Lavenex et al. 2016; Geddes and Scholten 2016; Margheritis 2018). For example, there is clear evidence reported in this book of attempts to include migration and mobility, including schemes - or aspirations to develop such schemes - for intra-regional mobility in key regional groupings.

This introduction has two main tasks. The first is to break down this book's focus into its core components in order to specify more clearly what is meant by 'regional', 'migration' and 'governance'. Looking at each in turn provides the basis for a common vocabulary that allows the various chapters in this book to focus on the dynamics of cooperation (and non-cooperation) on migration and mobility in various types of regional setting. Its second task is to specify questions that help inform the common framework, which are addressed in each chapter and to which we return in the concluding chapter. Before undertaking these tasks, we begin with a brief exposition of the relationship between borders, boundaries, states and international migration to locate the analysis within the wider context of analyses of the global politics of migration.

\section{BORDERS, BOUNDARIES AND THE MAKING OF MIGRATION POLITICS}

International migration is defined as a social and political process by the presence of states and their borders. Without state borders, there would be no such thing as international migration (Zolberg 1989). These include the territorial 
borders of states that can be found at land, air and sea points of entry. At these territorial borders, would-be migrants can be asked to present a claim for entry and decisions are then made about whether access to the state territory be granted, for what purpose and for what duration. While most crossings of state borders occur in a regular fashion, it is also well known that considerable effort can also be made by would-be migrants and those who seek to facilitate their movement, such as people smugglers, to avoid state controls and cross borders irregularly. The wider analytical point is that it is the borders and boundaries of states that define international migration. An obvious extension of this argument is that states and their borders come in many different forms. Not only have there been important historical changes in the location and presence of state borders across the world, but it is also very clearly evident that the capacity of states to regulate their borders and entry to their territory can vary significantly.

It is not only these territorial borders and boundaries that play a key role in defining international migration. There are other kinds of borders that can also give meaning to international migration as a social and political process. In particular, organisational borders and boundaries more typically found within states rather than at their external frontiers can play a key role in defining international migration. In major destination countries, there are important relations between migration, social rights and the provision of welfare services as key organisational boundaries. This can work in two ways: migrants contribute through taxation and employment to help sustain welfare provision while migrants and their families also use welfare services. The purpose of this book is not to delve into this debate about migration and the welfare state, but to observe that these important organisational boundaries are 'internal' to states, but clearly play an important role in defining international migration as a social and political issue. Again, we must add the proviso that there is huge international variation in the provision of social rights and welfare. Some countries have highly developed welfare states while others struggle to guarantee basic social protections for their own citizens, never mind migrants.

To the impact of social rights and welfare states that tend to have a strong national resonance we can also add the role played by labour markets. Labour markets are often not strictly 'national', as they can cross national borders in complex production, supply and value chains. It is, however, clearly the case that international migration is powerfully defined by its relationship to employment and labour markets. How these labour markets are organised and how they relate to wider patterns of economic change plays an important role in shaping international migration. By this is meant economic effects articulated through employment and the labour market can shape definitions of 'wanted' and 'unwanted' migration and migrants, defined, for example, by skills or educational levels. There can also be tensions, paradoxes and even contradictions. 
In Southeast Asia, we see extensive reliance on temporary, contract-bound, labour migration into low-skilled employment. This labour migration is also strongly gendered, with men moving into sectors such as construction and women into domestic work. This reliance on migrant labour is accompanied by very limited and often inadequate structures at either national or regional level to guarantee or protect the rights of migrants (Piper and Withers 2018). Migrant workers are 'needed but not wanted', which is a familiar situation in other parts of the world too.

More nebulous, but with significant potential to affect debates about regional cooperation on international migration and mobility are conceptual boundaries of belonging and identity that play an important role in ideas about 'us' and 'them' (Anderson 2013). Who 'belongs' and on what basis has become an important component of debates about migration that reflect the forms of diversity that can result from international migration, as well as the onus that can be placed upon newcomers to adapt or 'fit' into the countries and societies to which they move. Again, we add a familiar proviso: there is huge temporal and spatial variation in how these ideas about belonging, entitlement and identity play out, as well as their effects on migrants and their families. The point we wish to emphasise is that these boundaries of belonging and identity also give meaning to international migration as a social and political issue by shaping views about which migrants in terms of their origins and characteristics are more welcome and by providing the basis on which acceptance and inclusion into destination countries can occur.

If these borders and boundaries are predominantly national then the question that arises is what space this leaves for inter-state cooperation on international migration at regional level? The most obvious answer to this is that international migration highlights interdependencies in the international system that can have a particular resonance at the regional level but interdependence does not necessarily lead to cooperation. There are two types of interdependence that are most relevant for this book's assessment of regional migration governance. The first is related to the structure of international migration as relations are forged between sending, destination and transit countries that can evolve into a complex relationship where international migration sees not only the movement of people across borders but also the exchange of financial and other resources, such as in the form of remittances, and the creation of other social, political and cultural linkages between countries of origin, destination and transit. The second type of interdependence is geo-political and occurs when geographically proximate states in regional settings see themselves to share similar challenges in relation to mobility and migration. They may, for example, see opportunities to develop closer cooperation to facilitate intra-regional free movement or to encourage responsibility-sharing in refugee protection. Alternatively, they may see cooperation as a means to 
enhance their capacity to regulate access to their territory. In both cases, what may ostensibly seem to be 'national' questions acquire a regional resonance linked both to the dynamics of migration itself and to the ways in which it can impact upon inter-state relations. Interdependence does not necessarily impel cooperation. International migration in the context of interdependence in the Middle East has played a more coercive role in relations between states (see Chapter 8). In North America, President Trump targeted Mexico and Mexicans for harsh anti-immigration rhetoric, threatened to tear up agreements with the Mexican government if it didn't control migration and demanded - without success - that Mexico pay for his infamous border wall (Chapters 9 and 10). In Southeast Asia and Europe, boat arrivals by migrants and asylum-seekers strained ideas about regional solidarity in the Association of Southeast Asian Nations (ASEAN) and the European Union (EU), respectively (see Chapters 5,6 and 11).

To further develop these points, we now unpack the three core elements of this book's analysis, beginning with the 'regional' component of migration governance.

\section{WHAT IS A REGION?}

There are no natural regions. Instead, regions are political constructs that centre on and can also seek to promote social, political, economic or organisational cohesiveness (Cantori and Spiegel 1970). Regional organisations are highly diverse in form, sit between the national and the international and reflect a multi-levelling of international politics with power and authority distributed across the sub-national, national, regional and international levels. This re-levelling is indicative of the multi-dimensional complexities of international governance.

A regional organisation can be defined as a grouping of states that are geographically proximate leading to perceived common interests derived from location and associated interdependencies. These include economic and trade-based interdependencies but can also include those linked to migration to and within the region.

A distinction can be made between regionalism understood as formal structures of regional cooperation and more informal patterns of interchange and exchange that occur within regional settings that can be labelled as regionalisation. There can, for example, be strong evidence of regionalisation in the form of population flows between countries in a particular regional setting that do not necessarily lead to regionalism in the form of structures that include provisions for migration and mobility. For example, there is a long and extensive migration relationship between Mexico and the United States, but the North American Free Trade Agreement (NAFTA, with agreement 
reached in 2018 for it to be superseded by the US-Mexico-Canada agreement) includes both countries, but in either its NAFTA or subsequent form contains no migration-related provisions. In North America we thus see regionalisation without regionalism.

Regional organisations are highly varied in their institutional form. For example, ASEAN has a strict consensus model for decision-making that requires unanimity from all ten of its member states. In contrast, the EU has a highly developed supranational system for its member states with independent institutions that have law-making powers, a European Parliament with legislative powers and law-making processes that can negate national vetoes.

Regional organisations tend to seek broad-based cooperation across a range of issues, but particularly centre on trade and economic cooperation. The inclusion of mobility provisions within regional organisations tends to be linked to the attainment of economic objectives. As this book shows, there are many and various regional organisations. A distinction can be made between regional organisations and sub-regional organisations, such as the 54-member African Union and sub-regional organisations within Africa, including the Economic Community of West African States (ECOWAS) and the Intergovernmental Authority on Development (IGAD) (see Chapter 7).

While there are many regional organisations, Hurrell (2007: 241) emphasises the importance of precision when noting that: "the underlying distinctions matter greatly and much regionalist analysis is muddled precisely because commentators are seeking to explain very different phenomena or they are insufficiently clear about the relationship amongst the varied processes described under the banner of "regionalism".

There was a reinvigoration of the study of regionalism after 1989 that led to a focus on a 'new regionalism' understood as an 'open' rather than a protectionist regionalism and defined as: 'the process by which actors, public or private, engage in activities across state boundaries and develop conscious policies of integration with other states' (Gamble and Payne 1996: 4). These references to the role of public and private actors and to a rescaling of political authority create clear links with the idea and practice of governance, but, before turning our intention to the meaning of governance, we first look more closely at what is meant by migration.

\section{WHAT IS INTERNATIONAL MIGRATION?}

International migration might seem a relatively straightforward matter: people move from one country to another and become international migrants. Just under 3 per cent of the world's population are international migrants, or around 244 million people (United Nations 2016). These figures do not include irregular migration, which, while highly significant, is, of course, difficult to 
measure. This introduces one distinction into the discussion of international migration, which is that between regular and irregular migration.

Another important distinction is between mobility and international migration. Stricto sensu, international migration is a form of population mobility, i.e. that part that involves the crossing of state borders. Within regional migration governance systems, however, it is possible to distinguish between mobility as a type of international population movement enabled by regional cooperation that can take the form of free movement arrangements that facilitate passport-free travel between participating states, as well as potential access to work and to social entitlements. ${ }^{1}$ In contrast, international migration is not enabled by the provisions of a regional agreement and requires the presentation of a passport and application of visa rules to govern the terms and conditions of entry. Regions may therefore induce openness between participating states but may also seek closure in relation to non-participating states.

Migration has often been classified as either permanent or temporary movement across borders as though these were the only two possible outcomes. In reality, migration can be more fluid. People may move for short periods (temporary migration) or move back and forth (circular migration). Migration can also open transnational spaces as people live their lives in more than one national setting and are investing and participating simultaneously in social relations embedded in more than one state and locality (Levitt and Glick Schiller 2004).

Another major distinction is between forced and voluntary migration with migrants divided between those that 'need admission' (forced) and those that 'want admission' (voluntary) (Walzer 1983). Forced migration is governed by international protection regimes, most importantly the 1951 UN Refugee Convention and its 1967 Protocol, as well as by regional frameworks such as the 1984 Cartagena Declaration in Latin America. Other forms of migration, in contrast, remain largely regulated at national level. The legal focus on persecution as a basis for the granting of refugee status does neglect the role that other factors, such as poverty, can play in forced movements. Being poor is not a basis for a claim to refugee status, but can be a reason why people feel forced to move. Rather than thinking of forced versus voluntary migration in a dichotomous way, these types of movement can be viewed along a continuum with changing degrees of freedom and choice available (Faist 2000). Many, often intertwined, factors influence whether a person or a family chooses to and eventually is also able to migrate. Migration drivers, including those for asylum-seeking migration, are often multi-faceted and are rarely unicausal. Migration infrastructures in turn, including regulatory frameworks, affect whether migration is seen as a viable option, and whether this option is realised. It is important to note that many would-be migrants can be stuck in involuntary immobility (Carling 2017). Categories such as 'temporary' or 
'permanent', 'forced' or 'voluntary' reflect political structures and interests. They are not inherent qualities of people on the move. Above all, such categories are manifestations of the governance of international migration, to which we now turn.

\section{GOVERNANCE}

The term governance is much used, although often with more attention paid to the adjectives attached to it (multi-level, experimental, regulatory, pluricentric, networked, deliberative to name six) than to the meaning of the term itself. Governance is generally seen as 'a signifier of change', by which could be meant change in the meaning, processes, conditions or methods of governing (Levi-Faur 2012: 7). Peters (2012: 19-22) recognises the 'ambiguity' of the concept before noting that 'successful governance' has four functional requirements: goal selection with these integrated across all the levels of the system; goal reconciliation and coordination to establish priorities; implementation; and feedback and accountability as individuals and institutions must learn from their actions.

We develop an understanding of governance that is related to the specificity of international migration. This understanding proceeds from the basic observation that international migration happens because other things change, i.e. it is epiphenomenal. These changes may be economic, political, social, demographic or environmental. For example, relative inequalities of income and wealth can be key drivers of international migration. So too can be political factors linked, in particular, to the effects of conflict either within or between states. These economic and political factors can be powerfully affected by the existence of migration networks linking would-be migrants to those who have already migrated. This imparts a social dimension to international migration. It is also the case that younger people are more likely to migrate than older people and that the demographic structure of a population can interact with economic and political change as well as with the social effects of migration networks to stimulate and channel international migration. Finally, the effects of environmental and climate change can interact with people's livelihoods to cause people to migrate. The point that we can take forward from this is that migration governance is necessarily related to a much wider set of economic, political, social, demographic and environmental conditions.

Migration governance centres on the various roles and actions of organisations. These may be organisations with specific migration responsibilities or for which migration is part of their remit. These governing organisations must try to make sense of what is going on 'out there' and also, on the basis of the understandings that they develop, decide what to do next. Migration governance as an organisational process can thus be understood to possess 
a dual meaning as, first, efforts to conceptualise the effects of change in underlying social systems. As already noted, these are economic, political, social, demographic and environmental. Second, governance systems will seek to steer, manage or coordinate these effects. This steering, management and coordination can and does involve regional organisations of varying types and with varying degrees of involvement in migration governance. As noted earlier, this governance occurs within a multi-level system within which states continue to play a key role but within which we can see increased involvement by regional organisations. It is also important to note that multi-levelness has a dimension related to the spatial allocation of authority across the sub-national, national, regional and international levels. It is also possible to observe changes in the actor composition of governance networks with involvement by public and private actors. Finally, the development of regional cooperation signifies the presence of more - not fewer - organisations in the migration governance field. This reinforces the point that migration governance is an organisational process defined by the relationship between governing organisations and the environment within which they operate. These governing organisations must seek to respond to pressures from their environment but, through their actions, can also play a powerful role in shaping their environment.

The role that governance organisations can play in shaping their environment leads to a final observation about governance. There can be a tendency to explore the effects of international migration on regional governance systems and to understand international migration as a challenge to these systems. It is, however, the case that governance systems, including those at regional level can play a powerful role in defining the challenge or problem that is to be addressed and also, through their wider economic and political effects, powerfully affecting the drivers of international migration. We need to understand governance systems, including those at regional level, as potential shapers of their environment and not merely as passive or reactive.

\section{COMPARING REGIONAL MIGRATION GOVERNANCE}

The comparability of regions depends not only on the research questions but also on the discursive and practical contexts in which the (social) construction of the region occurs (De Lombaerde et al. 2010; Geddes 2012; Börzel and Risse 2016). This book centres on migration-related discourses and practices that lead to migration governance outcomes.

To facilitate comparison, our approach focuses on the essential characteristics of regions, governance and regional migration governance. At the same time, these characteristics capture specific regional dynamics that differentiate them from non-regions. As previously noted, regions are political and social constructs that aim to promote cohesiveness. Regions can then interact with 
other regions with regard to migration governance as well as with the international governance level.

These interactions can form part of diffusion processes. As a consequence of interdependence, regions could look to other regions for examples of problem-solving, to legitimise certain decisions or because they consider that behaviour appropriate. Diffusion is a social process in which regions are active agents that choose which practices they will or will not emulate or which prior example they will or will not follow. They could also choose to promote their own practices. Diffusion processes rarely lead to institutional isomorphism, that is, to complete convergence or adoption of specific migratory measures. More often they lead to selective adoption, adaptation and/or transformation (Risse 2016). Persistent divergence in patterns of regional migration governance means that the regional system can be located within an international migration 'regime complex' comprising loosely coupled systems of institutions without an overall architecture to structure the whole set. This can lead to migration governance regimes coexisting in the same issue-area without a clear hierarchy (Keohane and Victor 2010: 4).

The understanding of governance developed in the previous section helps us to move beyond state-centric approaches to include non-state actors as active policy-making agents and, thus, to explore the link between the processes of regionalism and regionalisation in multi-level contexts. In governance processes governmental and non-governmental actors interact and take part in formal and informal institutions and policy-making, including coalitions and policy networks (see Börzel 2016).

The analyses that follow do not consider any particular regional organisation either as a model or template for others or as a unique case to be understood only in relation to its own specificities. Rather, regional migration governance experiences can be assessed alongside each other to establish an analytical dialogue. Assessment of the scope for diffusion of ideas and practices within and between regions can help to develop understanding of differences, commonalities and interactions. This approach also builds from the social nature of regional constructs, recognising their pluralism, and analysing interactions between the national, regional and international levels. By doing so, we develop a truly global perspective of both the discursive and practical context of migration and mobility to address a set of key questions that we now specify.

\section{ORGANISATION OF THE BOOK}

The chapters in this book address a series of questions that analyse not only the dynamics of regional migration governance, but also the interactions that occur within and between regional migration governance systems and the types of 
migration governance they produce. We are conscious too that debates about migration governance are nested within much wider debates about the state and international relations in each of our regions. Contributors are sensitive to the traditions within each region from which regional governance processes emerge, as well as the factors at regional level that can generate cooperation, tension or conflict on issues related to international migration.

The first set of questions relates to the role of regions in migration governance. Our contributors analyse the relevance and position of migration in regional cooperation and integration and the extent to which aspects of mobility and migration have been included in specific regional governance systems. This means identifying the factors that can account for the incorporation of mobility and migration within specific regional settings, the form that cooperation has taken and the forms or types of migration that have been the focus for cooperation. We see markedly 'uneven' governance with both more formal and informal structures and processes.

The second set of questions relates to structures and actors/action. All contributors share an interest in the relationships between structures, processes, actors and the context in which they act. Regional migration governance is a multi-actor field comprising, for example, national governments, regional organisations, business groups, employers, trade unions, international organisations, civil society organisations, think tanks and academic researchers. Power in migration governance is not equally distributed. Some actors - more often than not at state level - wield considerably more power and influence in regional migration governance systems. The chapters in this volume are sensitive to both the relationships between structures and actors and to the power relations that these encapsulate.

The third set of questions relates to the comparative dimension. Across time and space, the chapters in this book compare regions, not only to understand similarities and differences, but also to understand how, why and with what effects ideas and practices about migration governance can travel between regions. One thing to emphasise from the outset is that the EU is not taken-for-granted as a model or template. The EU arose from highly specific conditions and ideas about the 'sharing' or 'pooling' of national sovereignty that are not evident in other regions. It would be Eurocentric and limiting to use the EU as the standard by which we judge cooperation and integration in other regions. It is true that ideas and practices can travel. It is also true that regions may look to the EU. But, as we also see, this can include viewing the EU as a negative example, as occurred in South America during the 2000s.

To begin with, in Chapter 2, the book provides a conceptual overview of the dynamics of regional migration governance. Lavenex and Piper survey approaches that they label 'top down' and 'bottom up' and by doing so reveal the multi-level and multi-actor complexities of regional migration governance. 
Chapter 3 then picks up this theme by exploring specific forms of regional cooperation in South America through what are known as regional consultations. Finn, Doña-Reveco and Feddersen show how the sharing of ideas and practices through regional consultations in South America can shape national laws and practices. Chapter 4 maintains the focus on South America to consider explicitly the influence of EU provisions governing free movement and mobility on developments in South America. Brumat and Acosta periodise the development of MERCOSUR to highlight some early EU influences but identify more recent divergence with the EU seen as a counter-example against which regional migration governance in South America has been defined. Chapter 5 switches the focus to the EU. Geddes shows how it is understandings of what is 'normal' rather than experiences of 'crisis' that have played a key role in driving regional migration governance in Europe. Crises tend to affirm underlying understandings about the causes and effects of international migration, particularly of the potential (real or imagined) of large-scale migration to Europe. Chapter 6 identifies a key dynamic in contemporary regional migration governance, which is inter-regional relations. Through an assessment of the EU-Tunisia relationship in the context of the externalisation of EU migration governance to North Africa and beyond, Lixi highlights not only the complexity of interactions and the range of actors involved but also how changes in the composition of actors in Tunisia after the 2011 revolution have impacted upon relations with the EU. Chapter 7 delves deeper into the characteristics of regional migration governance in Africa through assessment of ECOWAS and the IGAD in East Africa. Dick and Schraven emphasise how differences in structures and processes are embedded in regional traditions and histories. Chapter 8 explores the politics of migration interdependence in the post-Arab Spring Middle East to show that migration interdependencies need not necessarily generate inter-state cooperation. Tsourapas shows how labour migration forms part of coercive inter-state relations within a regional migration governance context and where ostensibly weaker states can use migration as a non-military coercive strategy against more powerful states. Chapter 9 maintains a focus on what could be called 'weak regionalism' through assessment of migration governance in North America. Hadj Abdou shows that the fortification of borders and liberalisation of markets are not necessarily contradictory, but, instead, become closely linked as security and identity concerns interact with economic and business interests. Chapter 10 then extends the focus on north and central America through assessment of Mexico's role in regional migration governance. Vera Espinoza shows how a 'policy of depoliticised policy' has enabled Mexico to balance its relations to both north and south as well as how this approach is challenged by political changes and by associated changes in migratory dynamics. Chapter 11 explores regional migration governance in another region where there are significant limits to 
the reach and efficacy of regional structures. Rother shows how in Southeast Asia only limited spaces for regional migration governance have been opened and also makes an important distinction between governance of, for and by migration and migrants that highlights the need to be attentive to power relations in regional migration governance. Chapter 12 extends the geographic focus north to explore developments in the post-Soviet space and Eurasian region. Leonov and Korneev show how Eurasian regionalism has served to re-integrate the previous Soviet space because of the economic, social and cultural significance of migration in the region. Chapter 13 concludes the book by drawing lessons from the chapters and considering the significance of regional migration governance for the global governance of migration.

\section{NOTE}

1. While our understanding of mobility is broadly informed by the mobility turn in social sciences and the social implications of diverse forms of mobility, here we refer specifically to mobility within an institutional framework of regional integration processes (see Lavenex et al. 2016). For the mobilities paradigm see Sheller and Urry (2006) and Cresswell (2010).

\section{REFERENCES}

Anderson, B. (2013), Us \& Them? The Dangerous Politics of Immigration Control. Oxford: Oxford University Press.

Börzel, T.A. (2016), Theorising Regionalism: Integration, Cooperation and Governance, in Tanja A. Börzel and Thomas Risse (eds) The Oxford Handbook of Comparative Regionalism, pp. 41-63. Oxford: Oxford University Press.

Börzel, T.A. and Risse, T. (2016), The Oxford Handbook of Comparative Regionalism. Oxford: Oxford University Press.

Cantori, L.J. and Spiegel, S.L. (1970), The International Politics of Regions: A Comparative Approach. Englewood Cliffs, NJ: Prentice Hall.

Carling, J. (2017), How Does Migration Arise, in Marie Auliffe and Michele Klein Solomon (eds) Ideas to Inform International Cooperation on Safe, Orderly and Regular Migration, pp. 19-26. Geneva: IOM.

Cresswell, T. (2010), Towards a Politics of Mobility. Environment and Planning D: Society and Space, 28 (1), 17-31.

De Lombaerde, P., Söderbaum, F., Van Langenhove, L. and Baert, F. (2010), The Problem of Comparison in Comparative Regionalism. Review of International Studies, 36 (3), 731-753.

Faist, T. (2000), The Volume and Dynamics of International Migration and Transnational Social Spaces. Oxford: Oxford University Press. 
Gamble, A. and Payne, A. (1996), The Political Economy of Regionalism and World Order, in Andrew Gamble and Anthony Payne (eds) Regionalism and World Order, pp. 1-20. London: Macmillan.

Geddes, A. (2012), Regions and Regionalism, in Marc R. Rosenblum and Daniel J. Tichenor (eds) The Oxford Handbook of the Politics of International Migration, pp. 573-593. Oxford: Oxford University Press.

Geddes, A. and Scholten, P. (2016), The Politics of Migration and Immigration in Europe, 2nd edition. London: Sage.

Hurrell, A. (2007), On Global Order: Power, Values and the Constitution of International Society. Oxford: Oxford University Press.

Keohane, R.O. and Victor, D.G. (2010), The Regime Complex for Climate Change, Discussion Paper 10-33, January, The Harvard Project on International Climate Agreements.

Lavenex, S., Givens, T.E., Jurje, F. and Buchanan, R. (2016), Regional Migration Governance, in Tanja A. Börzel and Thomas Risse (eds) The Oxford Handbook of Comparative Regionalism, pp. 457-486. Oxford: Oxford University Press.

Levi-Faur, D. (2012), From 'Big Government' to 'Big Governance', in David Levi-Faur (ed.) The Oxford Handbook of Governance, pp. 3-19. Oxford: Oxford University Press.

Levitt, P. and Glick Schiller, N. (2004), Conceptualizing Simultaneity: A Transnational Social Field Perspective on Society. International Migration Review, 38, 1002-1039.

Margheritis, A. (ed.) (2018), Shaping Migration between Europe and Latin America. New Approaches and Challenges. London: ILAS Publications.

Peters, G. (2012), Governance As Political Theory, in David Levi-Faur (ed.) The Oxford Handbook of Governance, pp. 19-32. Oxford: Oxford University Press.

Piper, N. and Withers, M. (2018), Forced Transnationalism and Temporary Labour Migration: Implications for Understanding Migrant Rights. Identities, 25 (5), 558-575.

Risse, T. (2016), The Diffusion of Regionalism, in Tanja A. Börzel and Thomas Risse (eds) The Oxford Handbook of Comparative Regionalism, pp. 87-108. Oxford: Oxford University Press.

Sheller, M. and Urry, J. (2006), The New Mobilities Paradigm. Environment and Planning A, 38 (2), 207-226.

United Nations (2016), International Migration Report 2015, accessed 3 August 2018 at http://www.un.org/en/development/desa/population/ migration/publications/migrationreport/index.shtml.

Walzer, M. (1983), Spheres of Justice. Oxford: Oxford University Press.

Zolberg, A. (1989), The Next Waves: Migration Theory for a Changing World. International Migration Review, 23 (3), 403-430. 